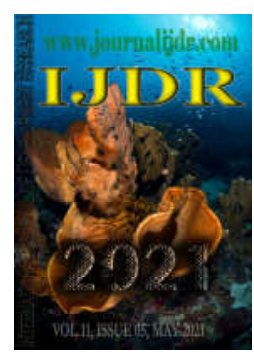

\title{
ANALYSIS OF VERTICAL AND HORIZONTAL IMPULSION IN MALE HANDBALL ATHLETES FROM JOINVILLE-SC
}

\author{
${ }^{1,}{ }^{*}$ Cristianne Confessor Castilho Lopes, ${ }^{2}$ Luís Fernando da Rosa, ${ }^{3}$ Jean Carlos de Oliveira, \\ ${ }^{4}$ Daniela dos Santos, ${ }^{5}$ Paulo Sérgio Silva, ${ }^{6}$ Marilda Morais da Costa, ${ }^{7}$ Tulio Gamio Dias, ${ }^{8}$ Eduardo \\ Barbosa Lopes, ${ }^{9}$ Laísa Zanatta, ${ }^{10}$ Vanessa da Silva Barros, ${ }^{11}$ Mônica Confessor Castilho, \\ ${ }^{12}$ Heliude de Quadros e Silva and ${ }^{13}$ Youssef Elias Ammar
}

${ }^{1}$ University of Joinville Region - Joinville - SC; ${ }^{2}$ Joinville Region University - Joinville - SC ${ }^{3}$ Joinville Regional University - Joinville - SC; ${ }^{4}$ Alto Vale do Rio do Peixe University - Caçador - SC ${ }^{5}$ Uni Sociesc/Joinville - SC; 6 Lutheran Educational Association - IELUSC College - Joinville - SC ${ }^{7}$ School of Arts, Sciences and Humanities at USP - São Paulo - SP; ${ }^{8}$ Alto Vale do Rio do Peixe University - Caçador - SC; ${ }^{9}$ Universidade Alto Vale do Rio do Peixe - Caçador - SC; ${ }^{10}$ Universidade Alto Vale do Rio do Peixe - Caçador - SC; ${ }^{11}$ Federal University of Rio de Janeiro - Rio de Janeiro - RJ; ${ }^{12}$ Universidade Alto Vale do Rio do Peixe -

Caçador - SC; ${ }^{13}$ South University of Santa Catarina - Tubarão - SC

\section{ARTICLE INFO}

Article History:

Received $20^{\text {th }}$ February, 2021

Received in revised form

$17^{\text {th }}$ March, 2021

Accepted 27 ${ }^{\text {th }}$ April, 2021

Published online $30^{\text {th }}$ May, 2021

Key Words:

Vertical Thrust,

Horizontal Thrust,

Handball.

\begin{abstract}
Handball has become a popular sport because it is easy to learn and very common in Brazilian schools, mostly, given that it is an Olympic sport. The goal of this study is to analyze the vertical and horizontal impulsion index in male handball athletes from Joinville. The sample counted 17 athletes with ages ranging from 14 to 18 years old. Seventeen athletes belonging to the handball team of the city of Joinville were investigated. For data collection the tests were used: Sargent Jump Test (Sargent, 1921) and Lower Limb Explosive Strength Test (GAYA, 2016), in all jumps three attempts were performed and only the highest of them was taken into account for validation. After the results in the tests the athletes obtained in the Jump Without Assistance (SSA), 47.05\% of the athletes had a result considered GOOD, 35.29\% were considered REGULAR and $17.64 \%$ in the VERY GOOD. In the Sargent Jump with aid of upper limbs, with the nomenclature Jump with Aid (SCA), 41.17\% had jumps considered VERY GOOD, 35.29\% considered GOOD, $11.76 \%$ considered GREAT and 5.88\% considered REGULAR. In the lower limbs explosive strength test (TFEMI), $41.18 \%$ of the athletes were classified as VERY GOOD, $29.41 \%$ as GOOD, $23.52 \%$ as REASONABLE, and $5.88 \%$ as FAIL. After the conclusion of the data collection and analysis, the athletes in this study were classified with a jump considered good for their age group and most of the analyzed athletes had results higher than expected. The author highlights that with a more detailed study and with a more in-depth approach, so as to corroborate with other studies and with this one for future research.
\end{abstract}

*Corresponding author:

Cristianne Confessor Castilho Lopes

Copyright (C) 2021, Cristianne Confessor Castilho Lopes et al. This is an open access article distributed under the Creative Commons Attribution License, which permits unrestricted use, distribution, and reproduction in any medium, provided the original work is properly cited.

Citation: Cristianne Confessor Castilho Lopes, Luís Fernando da Rosa, Jean Carlos de Oliveira, Daniela dos Santos et al. 2021. “Analysis of Vertical and Horizontal Impulsion in Male Handball Athletes from Joinville-SC ”, international journal of development research, 11, (05), $47082-47088$.

\section{INTRODUCTION}

In sports it is common to see different types of jumps across different sports such as volleyball, basketball, athletics, handball, and others. These are sports that have different characteristics and explore different physical capabilities, however the power generated in the jumps becomes something common.
The current handball is a collective game, with the direct participation of the opponent in the actions, which the objective of one of the teams is to score a goal and the other tries to avoid it (Ferrari et al., 2020). Despite having numerous origins, many historians report different versions of the sport coming from China, Greece, Rome and France to polish what we see today. Nunes and Mattedi (2014) ay that despite the various systematizations and approximations, the way we know the sport today, the merit of handball's idealization in stadiums is 
attributed to German gymnastics teachers. Over the years, handball, being an Olympic sport, has become a sport where everyone can be a fan, and because it is easy to learn and common in Brazilian schools, it has become a popular sport. Oliveira et al. (2012) tell us that because the creator of the sport was a physical education teacher, handball naturally took greater impulse in the student environment. Therefore, since antiquity, it shows us how the sport can be spread in schools around the world. This study presents the relations of technical skills that are used to the sport, such as the jump. When talking about jumping for handball it is necessary to keep in mind that with the increasing specialization of the defensive system Menezes (2010) (6)and Menezes; Reis; Tourinho Filho (2015) say that the defensive systems aim to provide a collective organization in order to delimit the area of action of the attacking team or pointing the players to be marked, it has become necessary to improve the actions to overcome the markers, in this sense, Barbosa (2013) reports that throwing to the goal with impulse allows an advantage providing the attackera higher success rate when trying to score for his team.

For there to be an impulse many factors must be considered, for it to occur correctly and that way the movement is complete. According to Zakharov (1992), apud Almeida (2014) when jumping, multiple steps are involved, such as: the production of force needed to perform the action and the speed used to perform it, those are characterized by overcoming the body resistance as quickly as possible. The use of both vertical and horizontal impulsion is present in the dispute of a match and this can generate important advantages in offensive and defensive actions(10). The vertical impulsion requires a projection in the air in which the direction exceeds a period longer than a run, and horizontal that is longer than a step, being a basic motor skill, should always be stimulated to develop (Cotrim et al., 2011). According to DeSalles et al.(2012) the explosive force can vary in relation to its function, such as speed and the force provided by the muscles involved, thus the force applied in a jump will notbe applied only on the jumpitself but also in the very movements of the players of the sport. Bankoff (2010), tells us that the complexity of the jump cannot be explained simply through a fixed formula, which follows a preestablished pattern, it requires to have a deeper vision of the factors involved.

For Roschel; Tricoli; Ugrinowitsch (2011) the use of jumps generates different possibilities within a game, stirring specific skills and favoring motor performance, especially by vertical jumps. The athlete who makes use of some explosive effort, will always depend on the initial maximum force and its acceleration will depend on its external resistance, with this we understand that for the use of the impulse should not only be taken into account, but to what purpose should be this (Silva, 2017). Wisløff et al. (2004) showed a strong correlation between the ability in vertical jumps with the explosive strength of the lower limbs and the ability to perform short sprints in players of competitive level, Bankoff and Cruz (2010) also say that the explosive strength in the conditions of sports activity is manifested in regimes of dynamic muscle work, and must overcome an external resistance. With this, it results in a greater resultant of taking advantage of situations where the athlete will be employed in sports, being better used in situations where it is necessary to use them.

As physical abilities are determining factors in a sport, Jetelina (2013) says that the result in a vertical jump is preponderant for performance in sports, therefore tests that measure vertical and horizontal impulsion are fundamental for a more critical follow-up of athletes' performance. It also becomes a question of human development, and for this an important tool to measure the development are the tests applied to the athletes. Marinho and Marins (2012) report the importance of using motor tests in the evaluation, because besides providing information about the athlete's physical conditioning, it can be a basis for a possible intervention and change in the training method. Cotta et al. (2009) shows that most sports teams in Brazil or even abroad do not have the financial resources to obtain reliable results. Newton and Kraemer (1994) report that power becomes a determining factor in sports, because it provides a better athletic performance as in throwing or vertical jump. Thus, power is a determining factor and this study aims to understand this human behavior. In order to know more about a movement, it is necessary to evaluate this capacity in athletes, so that they can develop according to their interests and needs. This study seeks to analyze the vertical and horizontal impulsion of male handball athletes from Joinville, between the ages of 14 and 18. With the results obtained, besides comparing anthropometric data, it sought a comparison with other studies related to the same theme, besides relating a sport to others, and thus relating factors that can be used in programs designed according to the capacity of the teams for their athletes.

\section{METHODS}

The study presents a cross-sectional design, with a quantitative method and supported by a literature review. The instruments used were the vertical impulsion test Sargent Jump Test (1) and the horizontal impulsion test called lower limb explosive strength test (2), with favorable opinion number 4.101.611, under CNS Resolution 466/12. The research was conducted between August and September 2020, after supervised collection in the pilot study. The Informed Consent Form (ICF) was signed by the parents or guardians of each adolescent included in the investigation, ensuring the anonymity of the information; the Term of Consent was filled out by the athletes to certify that they were aware of the research conducted; the Authorization for Image Use was also signed in order to use the image of the participants to record the work and also for material for possible future projects. The researched group was composed of 17 male athletes, aged between 14 and 18 incomplete years, belonging to the Associação Joinvilense de Handebol - AJHA, located in the city of Joinville - Santa Catarina. The data was collected in the sports court attached to the Expocentro Edmundo Doubrawa in the neighborhood of America in the city of Joinville in Santa Catarina.

The research was carried out during the respective training hours. The adolescents were initially presented with the objectives and relevance of the study, as well as the clarification of possible doubts, and in all phases of the study we followed the biosafety protocol adopted by the World Health Organization (WHO) for interaction between people, with masks at all times, alcohol gel for applying the test and between each collection. For this study, athletes were included if they did not present any type of injury or were in the recovery phase, if they only practiced handball, had already participated in at least one championship and were connected to the association. Athletes who did not meet the inclusion criteria were excluded. As preliminary procedures the anamnesis and the ParQ were made to verify situations that could be aggravated by the test, the height, the wingspan and the body mass of the volunteers were also verified, in order to evaluate the homogeneity of the sample. After receiving instructions about the protocol used, the volunteers participated in a 10-minute warm-up session consisting of moderate running and small jumps. For the Sargent Jump Test (1), individuals pre-warmed up for ten minutes, then positioned themselves next to the wall keeping their feet on the ground and raising one arm to mark their total height. After obtaining the initial mark, the athletes performed a static vertical jump with the maximum possible impulsion marking with the fingertips the height obtained with the upper limb extended and with the help of the upper limbs to perform the jump movement, the test was performed three times to determine the maximum mark obtained. Test of explosive strength of lower limbs (horizontal jump)(2) athletes should be positioned behind a demarcation line and with the help of the upper limbs perform the highest jump they can, he will have three attempts to make the best mark and from that, evaluate the performance of athletes and analyze the result of all. Therefore, the objective of this study is to evaluate the explosive strength of the lower limbs in handball athletes and to compare it with other sports, to show how the development of athletes of this modality is in relation to others.

\section{RESULTS}

Due to the current pandemic scenario, a variation in the sample number, but still a total of 17 were present. By analyzing the data below in table 1 , one can see the standard deviation variations between: age, weight, height, height span, and total height. 
Table 1 - Results of the anthropometric evaluation of the athletes

\begin{tabular}{|c|c|c|c|c|c|c|c|c|}
\hline Age & & Weight ( & & Height (n & & Width (m & & Total height (m) \\
\hline Average & $\begin{array}{l}\text { standard } \\
\text { deviationd }\end{array}$ & Average & $\begin{array}{l}\text { standard } \\
\text { deviation }\end{array}$ & Average & $\begin{array}{l}\text { standard } \\
\text { deviation }\end{array}$ & Average & $\begin{array}{l}\text { standard } \\
\text { deviation }\end{array}$ & Average $\begin{array}{l}\text { standard } \\
\text { deviation }\end{array}$ \\
\hline 15,5 & $\pm 1,00$ & 73,47 & $\pm 10,77$ & 1,79 & $\pm 0,07$ & 1,85 & $\pm 0,08$ & $\pm 0,12$ \\
\hline
\end{tabular}

Table 2. Results from vertical impulsion tests following Sargent's protocol (1921)

\begin{tabular}{lll}
\hline \multicolumn{2}{l}{ Sargent Jump Test - Score with partial $(\mathrm{n}=17)$} & \\
Excellent & SSA & SCA \\
Great & $0(0,00 \%)$ & $0(0,00 \%)$ \\
Very good & $0(0,00 \%)$ & $2(11,76 \%)$ \\
Good & $3(17,65 \%)$ & $7(41,18 \%)$ \\
Regular & $8(47,06 \%)$ & $6(35,29 \%)$ \\
Weak & $6(35,29 \%)$ & $2(11,76 \%)$ \\
Very Weak & $0(0,00 \%)$ & $0(0,00 \%)$ \\
\hline
\end{tabular}

Table 3 - Results from the horizontal impulsion test performed following the Gaya and Gaya (2016) protocol

\begin{tabular}{lc}
\hline \multicolumn{2}{l}{ Lower Limb Explosive Strength Test - Score with partial $(\mathrm{n}=17)$} \\
\hline Weak & $1(5,88 \%)$ \\
Fair & $4(23,53 \%)$ \\
Good & $5(29,41 \%)$ \\
Very good & $7(41,18 \%)$ \\
Excellence & $0(0,00 \%)$ \\
\hline
\end{tabular}

Table 4. Relationship by age in the tests performed between 14 and 15 years old

\begin{tabular}{|c|c|c|c|c|c|}
\hline \multicolumn{6}{|c|}{ Relationship by Age of Test Results } \\
\hline \multirow{3}{*}{14 Years Old $(n=2)$} & SSA & Calculation & SCA & Calculation & TFEMI \\
\hline & 2,75 & 0,32 & 2,81 & 0,38 & 1,81 \\
\hline & 2,72 & 0,39 & 2,81 & 0,48 & 1,88 \\
\hline Media & 2,73 & 0,35 & 2,81 & 0,43 & 1,84 \\
\hline standard deviation & $\pm 0,02$ & $\pm 0,04$ & \pm 0 & $\pm 0,07$ & $\pm 0,04$ \\
\hline \multirow[t]{7}{*}{15 years $(n=7)$} & 2,71 & 0,45 & 2,87 & 0,59 & 2,05 \\
\hline & 2,68 & 0,37 & 2,72 & 0,41 & 1,85 \\
\hline & 2,64 & 0,49 & 2,65 & 0,50 & 1,95 \\
\hline & 2,55 & 0,34 & 2,60 & 0,39 & 1,62 \\
\hline & 2,72 & 0,40 & 2,83 & 0,47 & 2,14 \\
\hline & 2,87 & 0,41 & 3,02 & 0,56 & 1,96 \\
\hline & 2,72 & 0,50 & 2,78 & 0,56 & 2,27 \\
\hline Media & 2,70 & 0,42 & 2,78 & 0,49 & 1,97 \\
\hline standard deviation & $\pm 0,09$ & $\pm 0,05$ & $\pm 0,14$ & $\pm 0,07$ & $\pm 0,20$ \\
\hline
\end{tabular}

Table 5. Relationship by age in the tests performed among 16 to 17 year olds

\begin{tabular}{llllll}
\hline \multicolumn{2}{l}{ Relationship by Age of Test Results } & & & & \\
\hline \multirow{3}{*}{ 16 Years Old $(\mathrm{n}=3)$} & SSA & Calculation & SCA & Calculation & TFEMI \\
& 2,98 & 0,41 & 3,10 & 0,53 & 2,14 \\
& 2,78 & 0,41 & 2,84 & 0,47 & 1,92 \\
Media & 2,78 & 0,41 & 2,89 & 0,52 & 2,07 \\
Desvpad & 2,84 & 0,41 & 2,94 & 0,50 & 2,04 \\
& $\pm 0,11$ & \pm 0 & $\pm 0,13$ & $\pm 0,03$ & $\pm 0,11$ \\
17 years $(\mathrm{n}=4)$ & SSA & Calculation & SCA & Calculation & TFEMI \\
& 2,80 & 0,53 & 2,93 & 0,66 & 2,37 \\
& 2,89 & 0,39 & 2,96 & 0,46 & 2,2 \\
Media & 2,65 & 0,48 & 2,77 & 0,60 & 2,32 \\
standard deviation & 2,71 & 0,53 & 2,74 & 0,56 & 2,34 \\
& 2,76 & 0,48 & 2,85 & 0,57 & 2,31 \\
\end{tabular}

Table 6. Relationship between training time and the tests used - 1 year of training

\begin{tabular}{lcll}
\hline \multicolumn{2}{l}{ Relationship between training time and tests } & & \\
\hline 1 year $(\mathrm{n}=4)$ & SCA & SSA & TFEMI \\
& 2,65 & 2,77 & 2,32 \\
& 2,68 & 2,72 & 1,85 \\
& 2,76 & 2,83 & 2,14 \\
& 2,72 & 2,81 & 1,88 \\
Average and standard deviation & $2,70 \pm 0,04$ & $2,78 \pm 0,04$ & $2,04 \pm 0,22$ \\
\hline
\end{tabular}


Table 7. Relationship between training time and the tests used - 2 to 3 years of training

\begin{tabular}{llll}
\hline \multicolumn{4}{c}{ Relationship between training time and the tests used - 2 to 3 years of training } \\
\hline \multirow{3}{*}{2 to 3 years $(\mathrm{n}=8)$} & SCA & SSA & TFEMI \\
& 2,73 & 2,87 & 2,05 \\
& 2,55 & 2,60 & 1,62 \\
& 2,72 & 2,78 & 2,27 \\
& 2,98 & 3,10 & 2,14 \\
& 2,89 & 2,96 & 2,20 \\
& 2,78 & 2,84 & 1,92 \\
& 2,78 & 2,89 & 2,07 \\
Average and standard deviation & 2,87 & 3,02 & 1,96 \\
\hline
\end{tabular}

Table 8. Relationship between training time and the tests used - More than 4 years of training

\begin{tabular}{llll}
\hline \multicolumn{2}{l}{ Relationship between training time and the tests used - More than 4 years of training } & \\
\hline & SCA & SSA & TFEMI \\
More than $4(\mathrm{n}=4)$ & 2,80 & 2,93 & 2,37 \\
& 2,64 & 2,65 & 1,95 \\
& 2,75 & 2,81 & 1,81 \\
Average and standard deviation & 2,71 & 2,74 & 2,34 \\
\hline
\end{tabular}

Table 9. Results obtained in correlation between training time and the impulsion tests

\begin{tabular}{lll}
\hline \multicolumn{2}{l}{ Correlation between training time and jumps } & \\
\hline Training time x SSA & Training time x SCA & Training time x TFEMI \\
0,23 & 0,12 & 0,13 \\
\hline
\end{tabular}

Table 10. Correlation between the results of the vertical and horizontal impulsion tests

\begin{tabular}{lll}
\hline Correlation Table & \\
\hline SCA X SSA & SSA X TFEMI & SCA x TFEMI \\
0,95 & 0,34 & 0,36 \\
\hline
\end{tabular}

Table 11. Results of the impulsion tests within the BMI numbers of the athletes

\begin{tabular}{|c|c|c|c|}
\hline & SSA & SCA & TFEMI \\
\hline Underweight $<18,5(\mathrm{n}=2)$ & $0,45( \pm 0,05)$ & $0,51( \pm 0,01)$ & $2,01( \pm 0,08)$ \\
\hline Normal 18,5-24,9 $(n=10)$ & $0,42( \pm 0,06)$ & $0,50( \pm 0,08)$ & $2,06( \pm 0,23)$ \\
\hline Overweight $>25(n=4)$ & $0,40( \pm 0,08)$ & $0,47( \pm 0,09)$ & $1,99( \pm 0,24)$ \\
\hline
\end{tabular}

The jumps of the Sargent Jump Test (SJT) in its two variations called Sargent Jump without the aid of upper limbs, with the nomenclature used Salto sem ajuda (SSA), obtained a result where $47.05 \%$ of the athletes had a result considered GOOD, 35.29\% were considered REGULAR and $17.64 \%$ were considered VERY GOOD. In the Sargent Jump with the aid of upper limbs, with the nomenclature Jump with Aid (SCA), 41.17\% had jumps considered VERY GOOD, $35.29 \%$ considered GOOD, $11.76 \%$ considered GREAT and $5.88 \%$ considered REGULAR (Table 2). Below are the results of the tests cited above: In the lower limbs explosive strength test (TFEMI) (Table 3$), 41.18 \%$ of the athletes were classified as VERY GOOD, $29.41 \%$ as GOOD, $23.52 \%$ as POOR, and $5.88 \%$ as FAIL. Table 3 shows the score and percentage obtained in this test. It is also important to relate the exact amount of people who reached the results obtained among their categories in the tests, so each test had different numbers regarding how many people managed to reach the goal established among the hypotheses that would be between good or better in the tests. At the end of the tests (Table 4), it is known that there was a significant amount of samples that acquired marks higher than the stipulated GOOD. In SSA $58.8 \%$ of the samples scored above expected. In SSA $88.2 \%$ got above expected and in TFEMI $70.5 \%$ were considered within the stipulated target. When analyzing the data related to the ages (Table 5), the results show that between 14 and 15 years showed a higher result in the older ages, as it was expected, but, when analyzing the results the athletes of minor age obtained higher marks, but when analyzing according to Sargent's protocol (1921), the result was favorable to who was older, as it was also expected from the test. In the TFEMI, the results showed that the 15 -year-old athletes had greater strength in the lower limbs than the younger ones. Although the number of younger age samples was low, the table shows that despite their young age, they may have an expressive number, thus the small sample size may have interfered in the final result. The previous table also showed that younger ages scored higher than older ages, but according to the protocols used, those who were older were able to propel higher than the younger ones. In the TFEMI the dominance was absolute of those who were older, with a difference of more than 20 centimeters, which shows that by body development, the result would not be any different. For being of a sports team, there are many athletes that already follow for some years the practice of the modality, many of them already do it for years and for this fact many of the athletes already practice it for many years, but according to the table below there is a great variation in relation to the practice time in relation to the athletes' average, The variation reaches 5 years for the athlete who has practiced for more time, as well as 1 year for the athletes who have practiced for less time, so this question becomes so varied. With this, the average of the athletes was between 2.68 years of training, with a variation of \pm 1.35 in relation to the time of training. When relating the training time with the tests performed by this study, table 6 presents a correlation between the years of training in relation to the jumps obtained, by 
observing the table below one can see that athletes who have 2 or more years of training were better classified in the vertical tests, but in the horizontal test, those who had more than 4 years of training reached and more distant results because they already have a time of physical training improvement, so lower limbs power strength will be better applied in those who have more time of training. In table 6 , we can see the results for those who had 1 year of training, we can see that the maximum impulsion obtained by them came close to the other results, but for not having so much court time, it affected the achieved result, you can also see that with the low number of samples, it may have affected the result. The relationship between training time with the sample of 2 to 3 years (Table 7), it can be seen that the $\mathrm{n}$ is the majority in this division of athletes, it is also possible to see that the athletes in this category showed higher results in the vertical tests than the rest of the study, but did not get the same result in the horizontal test, despite being the majority in this, the experience factor caused the more experienced athletes to be better classified in the tests that were performed. We can see that despite the $n$ being low, the sample of more than 4 years of training, had only 4 samples (Table 8 ), the results achieved were better than the rest of the athletes, it was already expected that the experience factor and a more continued training were taken into account to achieve the marks obtained, even if they did not reach in all aspects the majority, this showed that they are more physically evolved to the point of using the explosive strength of lower limbs to use impulse in their sport practice.

With this fact it was also analyzed if there is a correlation between training time with the jumps used (Table 9), in this study, and showed that there is a correlation between them, the correlation between years versus jumps, showed some significance, in all the results showed that there is a relationship between them, but did not show significance between the correlations between the jumps because it is a non-significant result. From a more careful analysis, it found a correlation between the jumps. Table 10 shows that SSA versus SCA showed a correlation of 0.95 which is considered of strong relevance to the question at hand. In the SSA versus TFEMI the result pointed to 0.34 and in the SCA versus TFEMI 0.36 in both cases also showed that by the fact of measuring the explosive strength of lower limbs the correlations would point to be a positive result, despite not being a very expressive result, showed that they have some correlation, but that did not become significant in relation to the numbers, and with this measures the power of lower limbs. Another analysis was to use the Body Mass Index or BMI in the athletes to verify if there is a difference between the results through the classification obtained between the relation between weight and height. By analyzing table 11, we can see that in the SSA jump, the athletes with the underweight index obtained a higher result than the other classifications, but as the difference was minimal, the result achieved would not be so significant, considering that in the SCA the difference between them became almost none, almost an equal result with a slight drop for those with the overweight index. The difference that becomes more relevant would be in the TFEMI, because the mean value was almost equal to the others, but the athletes who are underweight had a result greater than the others with a difference of 5 centimeters, but when looking at the standard deviation one can see a difference between the total results, but this does not become so relevant because the "Normal" classification has more samples than the two other classifications together, thus and also because the BMI is an athlete, it becomes an unusable tool in this research.

\section{DISCUSSION}

When analyzing this with other studies we can mention Gonçalveset al. (2007) (21), that studied to establish correlation values between different tests of anaerobic power (Test RAST, in court and field; Wingate; Horizontal and Vertical Impulse) in young athletes of different sport modalities. For this, a sample of 159 athletes was used, 57 female and 102 male, distributed in the modalities futsal $(\mathrm{m} / \mathrm{f})$, volleyball $(\mathrm{m} / \mathrm{f})$, soccer $(\mathrm{m})$ and basketball $(\mathrm{m})$. The power strength of several sporting modalities that used tests of measurement of explosive strength of inferior members, and it can be noticed, although the $\mathrm{n}$ consisted of athletes with age above of this study that the averages of correlation are very close to the obtained result. As this study sought to analyze the capacity of explosive strength of lower limbs of handball athletes, this can be compared with the study of Gonçalves et al. (2007)(21), because, with both sought to analyze this power of lower limbs can correlate in research sense, but the author of the compared work used several sports (volleyball, basketball, soccer and futsal), and thus obtained results of correlation between the tests of vertical and horizontal impulsion with his researched modalities. The study by Gonçalves et al. (2007) used higher ages than this study, however one can have a basis of comparison between studies. Gonçalves et al. (2007) used several research instruments and one of them was the vertical and horizontal impulsion test and with this they also looked for the correlation between vertical and horizontal jumps. From this, a correlation between the studies is not so close, one of the factors may be the fact that the sample contains older ages than the researched sample of this study and so the difference may be due to this fact, another factor to have placed as a hindrance was that at the time of data collection the researched team was without an adequate training routine due to the SARS pandemic COV2 (COVID-19) and with this the results are not so close to the compared study. Another study by Mazzuco (2007) aimed to detect the anthropometric, physiological and technical indicators (specific motor skills) that can determine the performance of young soccer players, which had a sample of 48 athletes between 12 and 15 years old, members of pre-infantile and infantile teams of a professional soccer club. The study separated the samples between Pre-Childhood (PI) ( $\mathrm{n}=32 ; 12.95 \pm 0.54$ years old) and Children (IN) ( $\mathrm{n}=16 ; 14.85 \pm 0.44$ years old). The same tests as this study were used to assess lower limb muscle power, and to compare to this study we will use only the IN group. The result of Mazzucco's study (2007 was similar in relation to the numbers, but this study used ages above the compared study, it used ages between 14 and 18 years while the correlated study was only between 14 and 15 years and so it can be said that the studies are similar, in the matter of using minors in the research, but the fact that it contains samples that contain more age than Mazzucco's research (2007) may interfere in the comparison between the studies. Another study, this one from the Universidad Del País Vasco, UPV/EHU by Picabea and Yanci (2015) aimed to analyze the existing differences in vertical and horizontal jumping ability depending on the sport played (soccer, basketball and table tennis) and to determine if there was any relationship between horizontal and vertical jumping abilities.

With a number of 37 athletes as sample, aged 16-18 years (16 soccer players, 11 basketball players, and 10 table tennis players) were evaluated in the ability to jump vertically and horizontally. Anthropometric measurements were also included in this study and after measuring their anthropometric variables, Picabea and Yanci (2015), used the same tests to determine the outcome of their study with each sport and also correlating between them to determine their relationship between lower limb muscle power between sports. As the compared research used sports where power strength becomes a determining factor in performance within the sport, they used vertical impulsion tests to determine their result obtained, the result among the research and being similar in age and anthropometric values they become a more similar study for the comparison of results. This study for having an age base identical to this study becomes similar in terms of maturation of the sample researched, and when analyzing the characteristics amongst the studies it can be seen that both in all questions compare in anthropometric issues. It can be seen that this study had a better result in relation to the compared research, despite the fact that we are in a worldwide pandemic due to SARS-COV2 that in the meantime since the beginning of biosecurity measures made it so that there was no training for the surveyed athletes, nevertheless the results could be compared between the studies. When analyzing these studies we can observe that this study is in agreement with what literature has been presenting about the sense that the tests were used to determine the power of lower limbs. Following in this direction Falk and Pereira (2009) presented the study "Use of the horizontal jump as a comparative evaluation of lower limb strength in 
students of the soccer school of Grêmio de Lages - SC" which aimed to evaluate and compare the strength of lower limbs through the horizontal jump test of Matsudo (1995) in students of a soccer school, whose test is similar to the one used by this study. The sample included 15 athletes between the ages of 14 and 17 with more than a year of training and obtained positive results in their tests. According to the table below, the studies can be compared and it can be concluded that although they are different sports, the test results are similar in many aspects, but as this study includes athletes from a sport where the jump is a determining factor for good sports performance, there is a significant difference in the results. With the samples being similar in age and for having more than one year of training makes the study one of the bases for comparison, so the two studies can say that the use of impulsion tests can show the evolution of lower limb muscle power. The sense of this study with the related ones showed that the surveyed athletes are well conditioned.

\section{CONCLUDING REMARKS}

After the whole study it can be concluded that the athletes participating in this study were classified with a jump considered good for their age group and most of the analyzed athletes had results above the expected, despite the fact that we are in a global pandemic, the results characterized a good physical development pertinent to their modality exercised. From the literature studied also analyzed in other studies for the comparison of results and thus attribute a correlation between this study with other existing ones and this one showed a similar correlation in its results. Within this pandemic scenario, the results may have been negatively affected in relation to the physical capacity continued with the training proposed by the researched club, and may even vary the sample both in number, but also in the final result. The author points out that with a more detailed study and with a more in-depth approach regarding the type of research and the way of approach being continued, you can find more accurate and reliable results to be used in other types of research and thus corroborate with other studies and with this one for future research.

\section{REFERENCES}

Almeida MD de. Como tornar a periodização no treinamento esportivo mais eficiente: uma aproximação com a teoria das restrições [Internet]. 2014 [cited 2020 May 19]. p. 47. Available from: file:///C:/Users/Cris/ Downloads/Almeida Mauricio Davisde_TCC.pdf

Bankoff AD, Cruz EM. Estudo Do Salto Vertical Máximo: Análise Da Correlação De Forças Aplicadas. Conexões [Internet]. 2010 Apr 1;8(1). Available from: https://periodicos.sbu.unicamp. br/ojs/index.php/ conexoes/article/view/8637754

BARBOSA GL. Análise Biomecânica Do Arremesso Com Salto Em Alunos Praticantes De Handebol [Internet]. 2013 [cited 2020 Jun 14]. p. 29. Available from: https://repositorio.bc.ufg.br /bitstream/ri/4568/ 5/TCCG - Educação Física - Gustavo Luiz Barbosa.pdf

Cotrim JR, Lemos AG, Néri Junior JE, Barela JA. Desenvolvimento de habilidades motoras fundamentais em crianças com diferentes contextos escolares. Rev da Educ Física/UEM [Internet]. 2011 Dec 4;22(4). Available from: http://periodicos.uem.br/ ojs/index.php/RevEducFis/article/view/12575

Cotta, Rafael Martins; Barletta, Glauco; Monteiro, Antonio Carlos; Affonso, Claudinei de Oliveira; Santos WF. Utilização dos testes de salto vertical e salto horizontal para prescrição de treinamento pliométrico [Internet]. efdeportes. 2009 [cited 2020 Apr 29]. Available from: https://www.efdeportes.com/ efd131/prescricao-de-treinamento-pliometrico.htm

de Salles P, Vasconcellos F, de Salles G, Fonseca R, Dantas E. Validity and Reproducibility of the Sargent Jump Test in the Assessment of Explosive Strength in Soccer Players. J Hum Kinet [Internet]. 2012 Jun 1;33(2012):115-21. Available from: https://www.sciendo.com/article/10.2478/v10078-012-0050-4
Falk, Paulo Roberto Alves; PEREIRA DP. Utilização do salto horizontal como comparativo no método de avaliação de força de membros inferiores de alunos da escola de futebol do Grêmio de Lages, SC. efdeportes [Internet]. 2009; Available from: https://www.efdeportes.com/efd139/avaliacao-de-forcade-membros-inferiores.htm

Ferrari W, Dias G, Sousa T, Sarmento H, Vaz V. Comparative Analysis of the Offensive Effectiveness in Winner and Losing Handball Teams. Front Psychol [Internet]. 2020 Sep 25;11. Available from: https://www.frontiersin.org/article/ 10.3389/ fpsyg. 2020.547110/full

GAYA, Adroaldo Cezar Araújo; GAYA AR. PROJETO ESPORTE BRASIL: Manual de testes e avaliação [Internet]. 2016. Available from: https://www.ufrgs.br/proesp/arquivos/manualproesp-br-2016.pdf

Gonçalves HR et al. Análise de informações associadas a testes de potência anaeróbia em atletas jovens de diferentes modalidades esportivas. Arq Ciências da Saúde da UNIPAR [Internet]. 2007;11(2). Available from: file://C:/Users/Cris/Downloads/1521-5562-1-PB.pdf

Horta TAG, Bara Filho MG, Miranda R, Coimbra DR, Werneck FZ. INFLUÊNCIA DOS SALTOS VERTICAIS NA PERCEPÇÃO DA CARGA INTERNA DE TREINAMENTO NO VOLEIBOL. Rev Bras Med do Esporte [Internet]. 2017 Sep;23(5):403-6. Available from: http://www.scielo.br/s cielo.php?script $=$ sci arttext\&pid $=\mathrm{S} 1517$ $86922017000500403 \& \operatorname{lng}=$ pt\&tlng $=$ pt

Jetelina M. Comparação entre impulsão horizontal e vertical com e sem balanceio de braço em jogadores de futebol [Internet]. 2013. Available from: http://semanadoconhecimento. upf.br/download/anais-2013/biologicas/matheus jetelina167575-resumo-comparacao_entre_im.pdf

Marinho BF, Marins JCB. Teste de força/resistência de membros superiores: análise metodológica e dados normativos. Fisioter em Mov [Internet]. 2012 Mar;25(1):219-30. Available from: $\mathrm{http} / / /$ www.scielo.br/scielo.php?script=sci arttext\&pid=S0103$51502012000100021 \& \operatorname{lng}=$ pt\&tlng $=$ pt

Matsudo VKR. Teste em ciências do esporte. In: 5th ed. São Caetano do Sul; 1995.

Mazzuco MA. Relação entre maturação e variáveis antropométricas, fisiológicas e motoras em atletas de futebol de 12 a 16 anos [Internet]. Curitiba; 2007. Available from: https://core.ac.uk/download/pdf/151512173.pdf

Menezes RP, Reis HHB dos, Tourinho Filho H. Ensinoaprendizagem-treinamento dos elementos técnico-táticos defensivos individuais do handebol nas categorias infantil, cadete e juveniL. Mov [Internet]. 2015 Feb 5;21(1):261. Available from: https://www.redalyc.org/pdf /1153/115 33827 4020.pdf

Menezes RP. O Ensino dos sistemas defensivos do handebol: considerações Metodológicas acerca da categoria cadete. Pensar a Prática [Internet]. 2010 May 5;13(1). Available from: http://www.revistas.ufg.br/index.php/fef/article/view/7269

Newton, R. U.; Kraemer WJ. Developing explosive muscular power: implications for a mixed methods training strategy. J Strength Cond Res [Internet]. 1994;16(5):20-9. Available from: http://www.hydra-

gym.com/research/RSH_DevelopingExplosiveMuscluarPower withMixedMethodsofTraining.pdf

NUNES, Camila da Cunha; MATTEDI MA. No Title. Rev História do Esporte. 2014;7(2):1-30.

Oliveira, Paulo Sergio Pimentel de; Cocchiarale, Ney Felippe de Barros Rodrigues; Barão, Gladis Neves; Triani F da S. Handebol escolar: construindo conhecimento [Internet]. 2012. Available from: https://www.efdeportes.com/efd175/handebolescolar-construindo-conhecimento.htm

Picabea, J; YANCI J. Diferencias entre jugadores de fútbol, baloncesto y tênis de mesa en la capacidad de salto vertical y horizontal. Rev Iberoam Ciencias la Act Fis y el Deport [Internet]. 2015;4(2):9-25. Available from: https://core.ac.uk/download/pdf/214836099.pdf 
Roschel H, Tricoli V, Ugrinowitsch C. Treinamento físico: considerações práticas e científicas. Rev Bras Educ Física e Esporte [Internet]. 2011 Dec;25(spe):53-65. Available from: http://www.scielo.br/scielo.php?script=sci_arttext\&pid=S1807$55092011000500007 \& \operatorname{lng}=\mathrm{pt} \& \operatorname{lng}=\mathrm{pt}$

Sargent DA. The Physical Test of a Man. Am Phys Educ Rev [Internet]. 1921 Apr 14;26(4):188-94. Available from: https://www.tandfonline.com/doi/full/10.1080/23267224.1921.1 0650486
Silva, Deborah Sena da Silva; Jr, Dilmar Pinto Guedes; Cruz, Flávio Barbosa da; Scorcine, Cláudio; Pereira R. Efeito do treinamento de força no desempenho de atletas de arremesso e lançamentos do atletismo. 2017;5. Available from: https://portal atlanticaeditora.com.br/index.php/revistafisiologia/article/view/ 1137

Wisløff U, Castagna C, Helgerud J, Jones R, Hoff J. Strong correlation of maximal squat strength with sprint performance and vertical jump height in elite soccer players. Br J Sports Med [Internet]. 2004 Jun;38(3):285-8. Available from: http://www. ncbi.nlm.nih.gov/pubmed/15155427 